SCIEnTIA Marina 70 (3)

September 2006, 355-362, Barcelona (Spain)

ISSN: 0214-8358

\title{
Life history of the amphipod Corophium insidiosum (Crustacea: Amphipoda) from Mar Piccolo (Ionian Sea, Italy)
}

\author{
ERMELINDA PRATO and FRANCESCA BIANDOLINO \\ Istituto Sperimentale Talassografico, I.A.M.C - C.N.R., Via Roma, 3, 74100 Taranto, Italy. \\ E-mail: linda.prato@iamc.cnr.it
}

\begin{abstract}
SUMMARY: A one-year study was conducted on the life history of the amphipod Corophium insidiosum (Crawford, 1937) in the Mar Piccolo estuary (Southern Italy). Monthly collections were made to investigate certain aspects of population structure, abundance and reproductive biology. Population density showed a clear seasonal variation: with a maximum in springsummer and a minimum in autumn-winter. Although brooding females were present all year round, recruitment occurred in spring, decreased in summer, peaked in autumn and almost ceased during the winter. 7-8 new cohorts in all samples could be recognised from April 2002 to November 2002. Mean longevity was $\sim 5$ to 6 months, and the estimated lifespan was longer for individuals born in late summer than for individuals born in spring. The sex ratio favoured females with a mean value of 1.51 , but males grew faster and attained a larger maximum body length than females. Males and females became distinguishable at roughly $>2 \mathrm{~mm}$, reaching a maximum size of $5.6 \mathrm{~mm}$ for females and $6.0 \mathrm{~mm}$ for males during the winter months. The females reproduced for the first time when they reached $2.2 \mathrm{~mm}$ body length. The number of eggs carried by females was related to the size of the female.
\end{abstract}

Keywords: Corophium insidiosum, amphipod, life history, Mar Piccolo.

RESUMEN: Ciclo biológico del anfipodo Corophium insidiosum (Crustacea: Amphipoda) del Mar Piccolo (mar JónICO, ITALIA). - Se realizó un estudio anual sobre el ciclo biológico del anfípodo Corophium insidiosum (Crawford, 1937) en el estuario del Mar Piccolo (S de Italia). Se realizaron muestreos mensuales para investigar aspectos de la estructura de poblaciones, abundancia y de la biología reproductiva de la especie. La densidad de las poblaciones mostró una clara variación estacional con un máximo en primavera-verano y un mínimo en otoño-invierno. Aunque se observaron hembras con oosteguitos durante todo el año, el reclutamiento se dio en primavera, descendiendo en verano, alcanzando un pico en otoño y casi cesando en invierno. 7-8 nuevas cohortes pudieron ser identificadas en todos los muestreos desde Abril 2002 a Noviembre 2002. La longevidad media fue de $\sim 5-6$ meses, mayor en individuos nacidos en el final del verano que en aquellos nacidos en primavera. La relación hembras/machos fue favorable a las hembras con un valor medio de 1.51, aunque los machos crecieron más rápido alcanzando una longitud total mayor que la de las hembras. Machos y hembras empiezan a ser morfológicamente distinguibles entre ellos a partir de unos $2 \mathrm{~mm}$, alcanzando tallas máximas de $5.6 \mathrm{~mm}$ en hembras y 6.0 $\mathrm{mm}$ en machos, durante el perido hivernal. Las hembras se reproducen por vez primera una vez alcanzados los $2.2 \mathrm{~mm}$ de longitud total. El número de huevos por hembra fue proprcional al tamaño de las mismas.

Palabras clave: Corophium insidiosum, anfípodo, ciclo biológico, Mar Piccolo.

\section{INTRODUCTION}

Crawford described Corophium insidiosum in 1937 and separated this species from the closely related species C. bonnellii Milne-Edwards, 1830.
Females of both species are very similar morphologically.

C. insidiosum is a widespread and frequently recorded species along the European coast: in the Mediterranean Sea (Fischetti, 1937; Brian, 1939; De 
Casabianca, 1967, 1968; Krapp-Schickel, 1971; Anger, 1979; Myers, 1982), and in the North Sea and western Baltic Sea (Köhn, 1996). It is also recorded in the Atlantic Ocean (European and North American coasts) and the Pacific Ocean (west coast of America, Chile, Japan), (Crawford, 1937; Bousfield and Hoover, 1997).

This amphipod is found in high abundance in shallow, brackish inshore areas and estuaries with high turbidity, (Muus, 1967; Sheader, 1978; Kevrekidis, 2004). Furthermore, it has also been reported in organically polluted areas (Birklund, 1977).

This species is the most widespread amphipod in Mediterranean lagoons, mainly in sheltered sites which are close to the sea and which have high salinity values (Procaccini and Scipione, 1992; Kevrekidis, 2004).

The existing information on the life cycle of this species is mostly restricted to studies from north European countries (Birklund, 1977; Sheader, 1978; Nair and Anger, 1979).

C. insidiosum is tubicolous and both sexes build tubes of mucus and detritus. This marine amphipod has been observed feeding on deposited particles such as detritus, protozoans and diatoms (Dahl, 1973), but it mostly acts as a suspension feeder. It constitutes a food source for shrimps and young fish, since it occurs in the intertidal zone where waders feed on amphipods (Nair and Anger, 1979).

We researched the life cycle of $C$. insidiosum because this species is the dominant amphipod in the Mar Piccolo estuary (Ionian Sea, Italy). The present study provides some information on its seasonal changes in abundance, population structure and reproductive features. These data are also compared with other available data on $C$. insidiosum and other Corophium species from different geographical areas.

\section{MATERIALS AND METHODS}

The study site is located in Mar Piccolo estuary

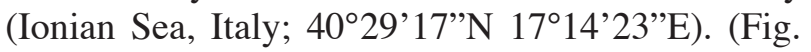
1). It is an inner, semi-enclosed basin with lagoon features characterised by restricted circulation and divided by two rocky promontories into two inlets called the First and Second Inlet, which have a maximum depth of 13 and $8 \mathrm{~m}$ respectively

We investigated the Second Inlet. Quantitative sampling of the amphipod population was per-

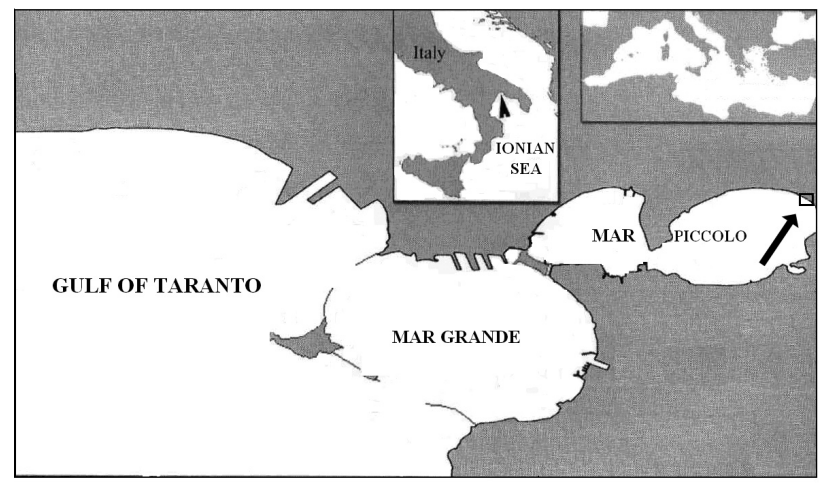

FIG. 1. - Geographic location of the sampling area.

formed monthly from April 2002 to March 2003. Three samples were taken randomly in a $300 \mathrm{~m}^{2}$ area using a square metal box ( $25 \times 25 \mathrm{~cm} ; 15 \mathrm{~cm}$ depth). The amphipods were transported live to the laboratory, where they were sorted from the other species of animals after sieving the sediments through a 350 $\mu \mathrm{m}$ mesh. The specimens were fixed with $4 \%$ formalin, counted and measured under a stereomicroscope fitted with a micrometer eyepiece body. Size was measured along the mid-dorsal line, from the tip of the rostrum to the tip of the telson.

The amphipods were classified as juveniles, females or males. Females were distinguished by the presence of oostegites and males by the penial papillae. Females were separated into three groups: 1) immature: with small and non-setose oostegites; 2) mature: with setose oostegites without embryos and 3) brooding females: with embryos or juveniles in the brood pouch. Sexual dimorphism was only evident in adult animals due to the size and shape of the rostrum and antennae 2. Below a body length of 2 $\mathrm{mm}$ it was difficult to separate the sexes, and these small immature individuals were classed as juveniles.

The total number of individuals collected in the quantitative samples $\mathrm{x} \mathrm{m}^{-2}$ was calculated each month for each sample.

The population was analysed by the graphical analysis of polymodal frequency distributions (Harding, 1949).

The sex ratio (females/males) of the population was estimated and deviations from unity were assessed with a $\chi^{2}$ test.

The embryos of each brooding female were counted and classified in the four developmental stages (A, B, C, D) described by Janssen et al. (1979) for the genus Gammarus.

The relationship between brood size (y) and 
TABLE 1. - Physical data of the sampling site.

\begin{tabular}{|c|c|c|c|c|c|c|}
\hline & 05/04/’02 & 08/05/’02 & 07/06/'02 & 12/07/'02 & 05/08/’02 & 09/09/'02 \\
\hline $\begin{array}{l}\text { Temperature }{ }^{\circ} \mathrm{C} \\
\text { pH } \\
\text { Salinity } \% o \\
\text { Dissolved } \mathrm{O}_{2} \mathrm{mg} / 1 \\
\text { Organic Matter \% }\end{array}$ & $\begin{array}{c}20.0 \\
8.64 \\
35.44 \\
8.58 \\
0.95\end{array}$ & $\begin{array}{c}21.4 \\
8.02 \\
35.82 \\
8.65 \\
1.17\end{array}$ & $\begin{array}{c}25.2 \\
8.64 \\
35.54 \\
6.20 \\
1.20\end{array}$ & $\begin{array}{c}30.0 \\
8.27 \\
34.45 \\
5.08 \\
1.31\end{array}$ & $\begin{array}{c}28.1 \\
8.28 \\
35.51 \\
5.95 \\
1.16\end{array}$ & $\begin{array}{c}24.3 \\
8.50 \\
36.11 \\
8.10 \\
1.52\end{array}$ \\
\hline & 08/10/’02 & 04/11/’02 & 07/12/'02 & 10/01/'03 & 11/02/'03 & 08/03/'03 \\
\hline $\begin{array}{l}\text { Temperature }{ }^{\circ} \mathrm{C} \\
\text { pH } \\
\text { Salinity \%o } \\
\text { Dissolved } \mathrm{O}_{2} \mathrm{mg} / \mathrm{l} \\
\text { Organic Matter \% }\end{array}$ & $\begin{array}{c}19.1 \\
7.90 \\
36.42 \\
7.50 \\
1.03\end{array}$ & $\begin{array}{c}14.5 \\
8.47 \\
34.67 \\
9.00 \\
1.06\end{array}$ & $\begin{array}{c}14.2 \\
8.50 \\
35.64 \\
8.15 \\
1.82\end{array}$ & $\begin{array}{c}9.0 \\
8.20 \\
36.21 \\
8.04 \\
1.91\end{array}$ & $\begin{array}{c}8.0 \\
8.15 \\
35.03 \\
7.07 \\
1.83\end{array}$ & $\begin{array}{c}13.2 \\
8.40 \\
35.04 \\
7.80 \\
1.27\end{array}$ \\
\hline
\end{tabular}

female body length (x) was analysed using a linear regression analysis.

Water temperature, salinity, $\mathrm{pH}$ and dissolved oxygen were measured monthly using a multiparametric sampler "ME CTD 1500".

\section{RESULTS}

Data on the values of physical factors in the area investigated during the whole study period are shown in Table 1. Water temperature varied from $30^{\circ} \mathrm{C}$ in July 2002 to $8^{\circ} \mathrm{C}$ in February 2003; salinity ranged from $34.45 \%$ o to $36.42 \%$; $\mathrm{pH}$ values varied in a normal range for estuarine water (7.90-8.64) (Perkins, 1974). Oxygen concentrations ranged from $5.08 \mathrm{mg} / \mathrm{l}$ to $9 \mathrm{mg} / \mathrm{l}$ and the organic matter of the sediment was constant enough $(0.95 \%-1.91 \%)$. There is a significant correlation between abundance of individuals in the samples and temperature $(\mathrm{r}=0.65 \mathrm{p}<0.05)$ but no other significant correlations were found between abundance and environmental factors.

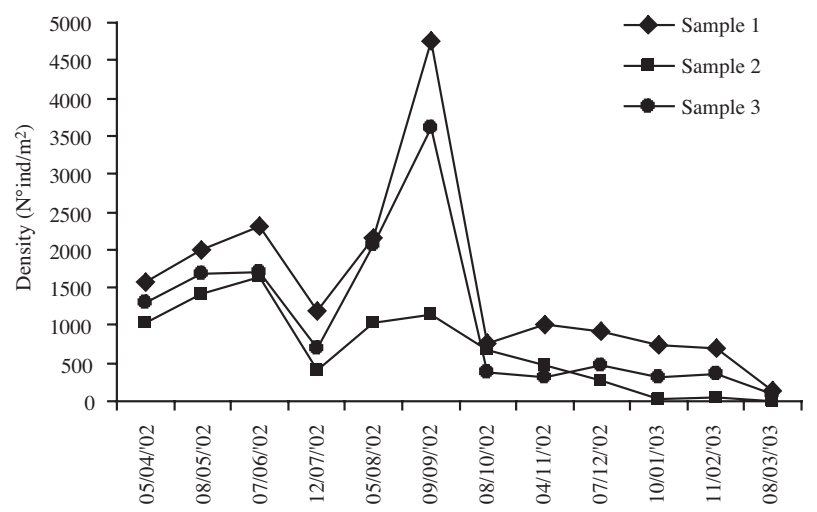

FIG. 2. - Monthly variation in population density $\left(\mathrm{ind} / \mathrm{m}^{2}\right)$ during the sampling period.
C. insidiosum is present throughout the year in Mar Piccolo. The seasonal variation in abundance followed a similar pattern in all samples: densities reached the highest values in spring-summer (except July) followed by a rapid decrease in autumn-winter (Fig. 2).

The occurrence of brooding females and the presence of juveniles in the population allowed the reproductive period to be determined. The monthly variations in frequency (\%) of brooding in the total female population and juveniles in the total population are shown in Figure 3.

Brooding females were found throughout the year showing higher values in spring and early summer followed by a decrease in autumn. Despite the presence of brooding females and mature females, breeding drastically decreased during the winter months and the production of offspring took place in April. The smallest brooding females were observed during the summer months. This seems to be linked to the fastest developing individuals with an advanced sexual maturation process. The monthly variation of immature, mature and brooding females

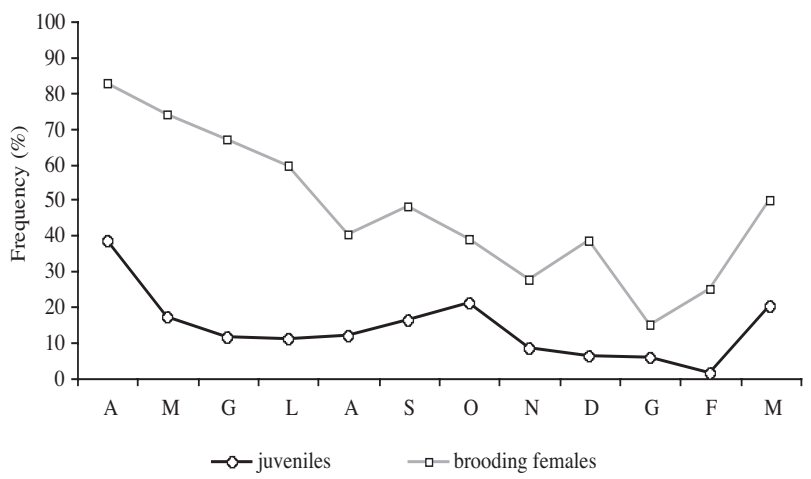

FIG. 3. - Monthly variations in frequency (\%) of brooding females (expressed as a percentage of the total number of females) and juveniles (as a percentage of the total number of individuals). 


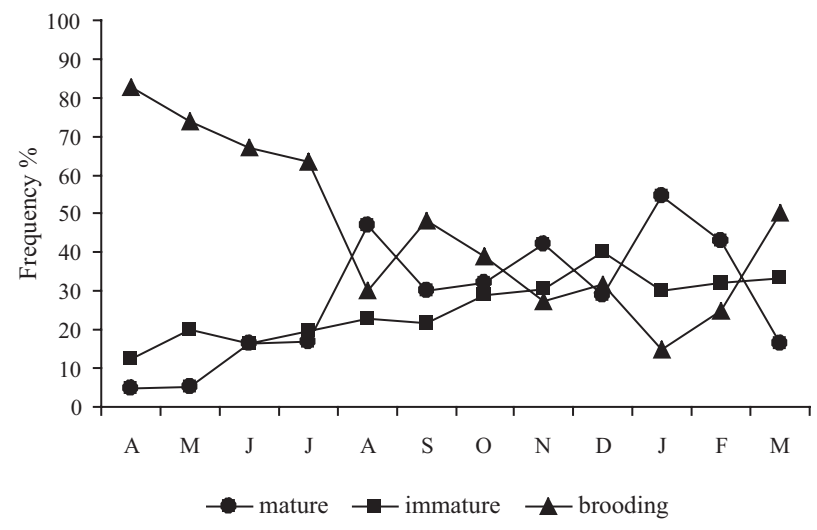

FIG. 4. - Monthly variation of the frequency of mature, immature and brooding females

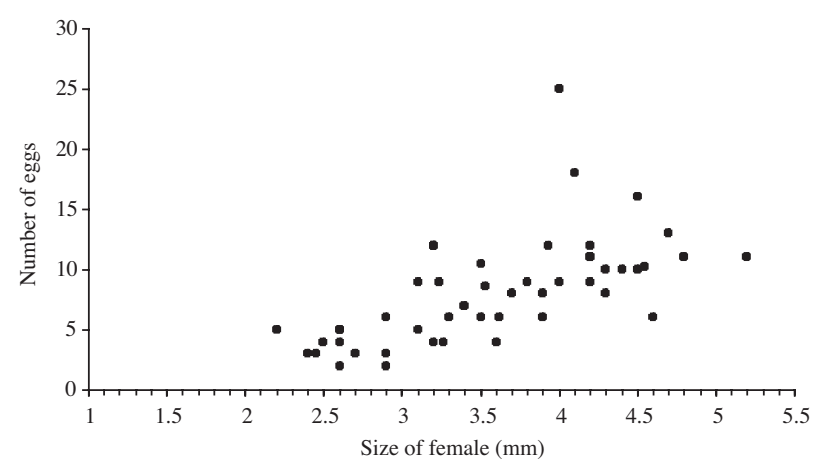

FIG. 5. - Dispersion diagram of the number of eggs in relation to the size of the female $(\mathrm{mm})$.

is represented in Figure 4. A relationship was found between brooding and mature females $(r=0.96$ $\mathrm{p}<0.005)$, brooding and immature females $(\mathrm{r}=0.80$ $\mathrm{p}<0.005)$ and mature and immature females $(\mathrm{r}=0.62$ $\mathrm{p}<0.05)$.

The relationship between the number of eggs per brood and female body length was statistically significant $(r=0.61 \mathrm{p}<0.005)$ (Fig. 5). In the winter months, females had a higher fecundity because of their larger size. The minimum size of a brooding female was $2.2 \mathrm{~mm}$ with 5 embryos, whereas the maximum brood size observed was 25 for a female of $4 \mathrm{~mm}$.

Mean brood size was higher at the start of development than at the later stages (Table 2). The eggs in the marsupium of a female were not always at the same development stage. Juveniles were also found inside the marsupium sometimes together with earlier egg developmental stages.

The sex ratio fluctuated throughout the study period and was biased in favour of females with the exception of May and February. In March the sex ratio was $1: 1$. The mean value in this study was

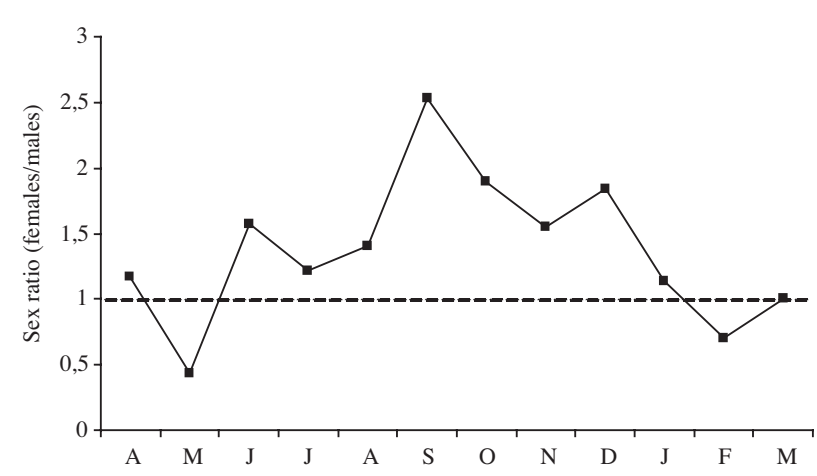

FIG. 6. - Monthly variation in the sex ratio of Corophium insidiosum.

1.37: $1\left( \pm 0.5\right.$ SD) (Fig. 6). Results of the $\chi^{2}$ test of deviation of the sex ratio $\left(\chi^{2}=172.74 ; \mathrm{df}=11\right.$ $\mathrm{p}<0.001)$ confirm the significance of the deviation from 1:1.

Figure 7 shows the size frequency histograms for males, females and juveniles in all sampling months. Males and females became distinguishable at roughly $>2 \mathrm{~mm}$, reaching a maximum size of $5.6 \mathrm{~mm}$ for females and $6.0 \mathrm{~mm}$ for males during the winter months.

The population was analysed according to the size frequency polymodal distribution for recognizable cohorts (Fig. 8). During the study period 7 to 8 new cohorts in all samples could be recognised from April to November. An initial recruitment peak occurred in spring followed by a constant trend in summer. Then a new peak occurred in September followed by a decrease during the winter months.

Four cohorts could be identified in all samples on the first sampling date $(05 / 04 / 02)$ for which a sufficient number of individuals could be found to perform modal analysis. Taking into account the average body length at the moment of detection, cohort C4 was assumed to be new born.

Seven new cohorts were identified during the next eleven months. The minimum average size at the moment of recovery ranged from $0.8 \mathrm{~mm}$ in sample 1 (October) to $2.0 \mathrm{~mm}$ in samples 2 and 3

TABLE 2. - Brood size of the embryonic stages and the percentage of females carrying embryos at these stages in the total number of brooding $C$. insidiosum females.

\begin{tabular}{lcc}
\hline $\begin{array}{l}\text { Embryonic } \\
\text { stage }\end{array}$ & $\begin{array}{l}\text { Mean brood size } \\
\pm \text { standard error }\end{array}$ & $\begin{array}{c}\text { Frequency of } \\
\text { female (\%) }\end{array}$ \\
\hline A & $7.27 \pm 3.5$ & 39.1 \\
B & $6.27 \pm 4.2$ & 28.5 \\
C & $5.93 \pm 1,5$ & 19.3 \\
D & $3.38 \pm 1.5$ & 13.1 \\
\hline
\end{tabular}




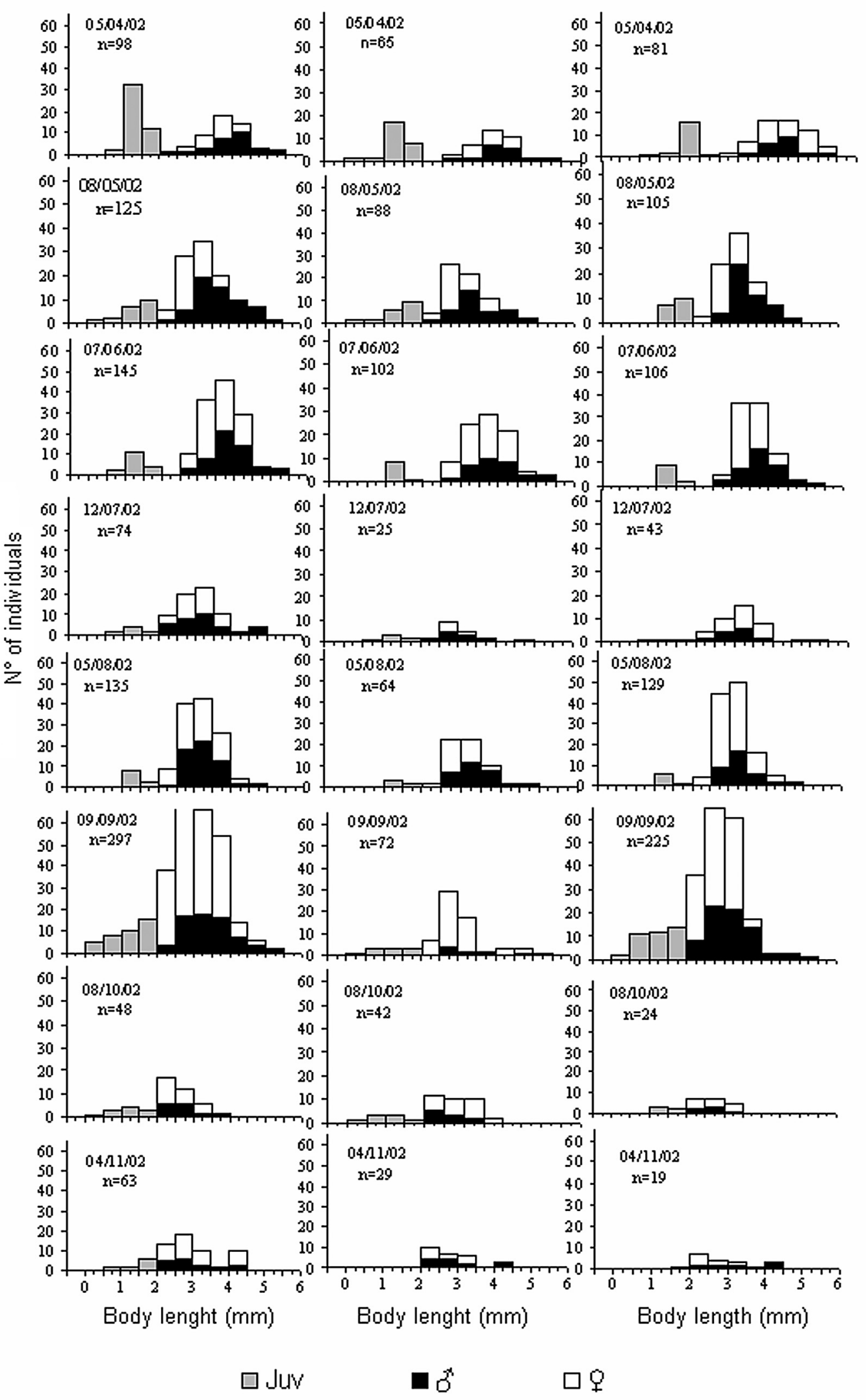

FIG. 7. - Size frequency distributions of males, females and juveniles; n: number of individuals. 


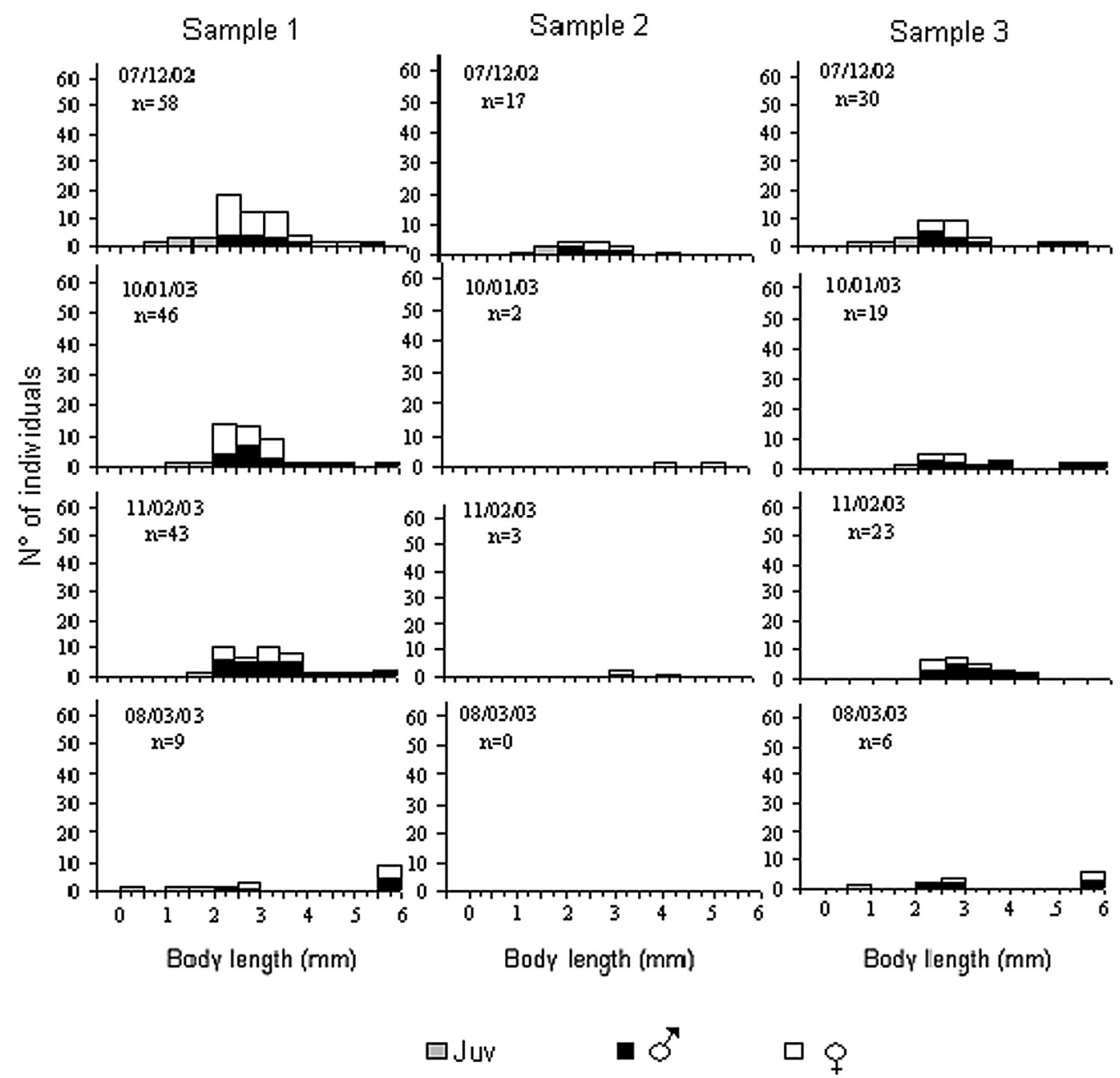

FIG. 7 (Cont.). - Size frequency distributions of males, females and juveniles; n: number of individuals.

(December and April respectively), while the maximum average size ranged from $2.5 \mathrm{~mm}$ to $6 \mathrm{~mm}$ in samples 3 and 1 respectively (February).

Size fluctuations also had a similar seasonality in females and males: mean lengths of both were high-

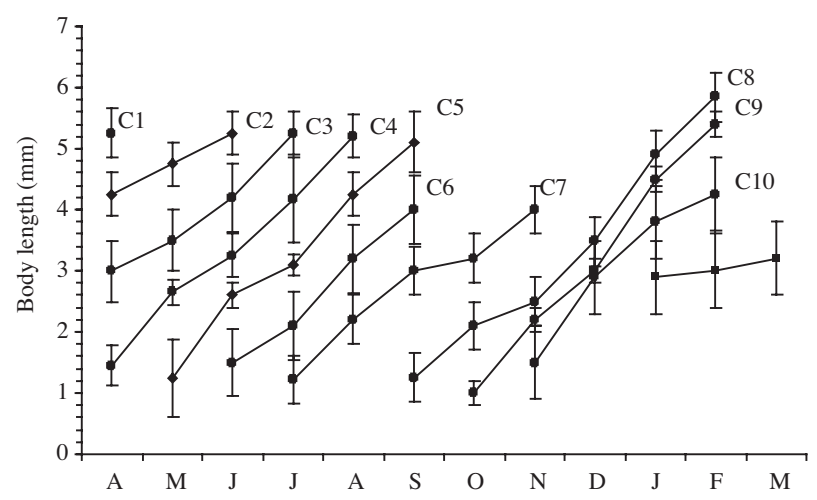

FIG. 8. - Development over time of the $C$. insidiosum populations; dots: mean body length; bar lines: standard deviation. est in winter and lowest in the summer and autumn months.

Cohorts born in spring still reproduced in the same season, but lived less time and did not survive the winter. Considering the disappearance of cohorts, their life span was estimated to be 4 to 5 months. The longest life spans were observed in cohorts born in late summer which have over-wintered and lived for a longer time (6 months).

\section{DISCUSSION}

Population density showed a clear seasonal variation with a maximum in spring-summer and a minimum in autumn-winter. The increase in population density in the spring and summer months is a natural consequence of recruitment, while the decrease in the autumn and winter months can be linked to both the end of the breeding season and to the tem- 
perature. Environmental factors such as temperature, salinity, oxygen concentration, quality and quantity of food may affect distribution and abundance of Corophium species. Low salinities in Buguglia lagoon, Corsica (Casabianca, 1972/73) and Monolimni lagoon, north Aegean Sea (Kevrekidis, 2004) caused mortality or/and emigration of $C$. insidiosum. In Areão, Portugal (Cunha et $a l ., 2000$ ), the long periods of high temperatures $\left(>24^{\circ} \mathrm{C}\right)$ and low oxygen content of the water increase the metabolic costs and can result in either mortality or emigration of $C$. multisetosum.

The reduction in population density reduces intraspecific competition (see Jensen and Kristensen, 1990 for C. volutator and C. arenarium), which favours breeding success. Extreme temperatures during the summer and winter may deter breeding, while moderate temperatures and salinity may be favourable for reproduction (Cunha et al., 2000).

In the same study area, seasonal variation in population density of G. aequicauda followed a pattern comparable to that of $C$. insidiosum (Prato and Biandolino, 2003).

Although brooding females were present all year in the $C$. insidiosum population, juveniles born in spring, grew, matured and became reproductively active during the summer months, giving rise to the next input of recruits in September-October. These represent the starting point of the overwintering generation, which grew during the colder months and reached larger sizes. Frequency of juveniles in the population decreased from November to February, which is associated with reduced adult breeding activity as the sea temperature decreases.

Corophium insidiosum's lifespan in Mar Piccolo fits the pattern known for this species from other Mediterranean areas (Casabianca, 1975; Kevrekidis, 2004).

Individuals born during late summer had a longer lifespan than those born in spring. A similar trend was observed by Moore (1981) for the C. bonnelii population at Milliport and for C. multisetosum in Ria de Aveiro (NW Portugal). Different populations of $C$. insidiosum display a reduction in lifespan with decreasing latitude and increasing temperature (Sheader, 1978; Casabianca, 1967; 1979; Labourg, 1968). This agrees with Nair and Anger (1979), who observed that an increase in temperature of $\sim 10^{\circ} \mathrm{C}$ reduces the lifespan of $C$. insidiosum by $\sim 2$ months.

During most of the study period, the sex ratio was favourable to females in Mar Piccolo. A female biased sex ratio appears to be the most common situation among Corophiidae (Sheader, 1978; Muskó, 1992; Rajagopal et al., 1999). Under laboratory conditions Nair and Anger (1979), observed a dominance of females in Corophium insidiosum and stated that males grew more slowly, matured at a smaller body size and age, attained a smaller maximum body length and lived for a shorter time than females. This was also observed by Kevrekidis (2004) in Monolimni lagoon. This contrasts with what was observed in Mar Piccolo where males grew more quickly and attained a larger maximum body length than females. However, growth, maturation, longevity differential rates and predation can all result in skewed sex ratios (Wenner, 1972).

The number of embryos produced per female increases with female size. Size at maturity is an important life-history parameter. Mature females of C. insidiosum were found at $2 \mathrm{~mm}$ length, and the first time females were observed brooding was when they reached a size of about $2.2 \mathrm{~mm}$. Brood size in amphipoda is often reported as being proportional to female body length (Beare and Moore, 1996; Costa and Costa, 1999; Persson, 1999 and Cunha et al., 2000). However, field studies suggest that environmental factors may also influence brood size. $C$. insidiosum in Mar Piccolo showed the same pattern observed in other populations of this species (mean 8.14 , range 5 to 25 embryos). A brood size of 4 to 25 embryos was reported in Arcachon by Labourg (1968); a range of 4 to 21 embryos in Kysing Fjord Denmark by Muus (1967) and 1 to 21 embryos in NE England by Sheader (1978). Kevrekidis (2004) states that low salinities in Monolimni lagoon might have caused a reduction in nutrient transfer to the gonads resulting in a smaller brood size than in other C. insidiosum populations (mean 4.96, range of 1 to 16 embryos). In laboratory cultures the brood size of C. insidiosum increased with increased temperature (Nair and Anger, 1979). Cunha et al., (2000) reported a predictive model of fecundity for $C$. multisetosum from Portugal, which gives an optimal temperature of around $18^{\circ} \mathrm{C}$ and low fecundity at low salinities. In Mar Piccolo, the highest brood size of the given size classes was recorded in April and October (20 to $19^{\circ} \mathrm{C}, 35.44$ to $36.42 \%$ respectively)

Brood size was higher in the early stages than in later stages with an egg loss of $53.5 \%$. This was also observed for the same species in Monolimni lagoon (53\% between stages 3 and 5) (Kevrekidis, 2004). This result was higher compared to that observed by 
Sheader (1978) for C. insidiosum (5 to $30 \%$ between early eggs and late eggs). In Mar Piccolo Gammarus aequicauda showed a decrease in brood size in the later stages compared to the brood sizes in the early stages, with an embryo number lower than $29.7 \%$. (Prato and Biandolino, 2003).

The results shown here are in agreement with the life history variations in Corophiidae and give new data on the species, since the biological and ecological information on this species is insufficient, especially concerning populations from southern European coastal areas.

\section{REFERENCES}

Anger, K. - 1979. Intersuchungen zum Lebenszyklus der Amphipoden Bathyporeia sarsi, Microdeutopus gryllotalpa, und Corophium insidiosum in der Kieler Bucht. Mitt. Zool. Mus., University of Kiel, 1(3): 1-6.

Beare, D.J. and P.G. Moore. - 1996. The distribution and reproduction of Pontocrates arenarius and P. altamarinus (Crustacea: Amphipoda) at Millport, Scotland. J. Mar. Biol. Ass. U. K., 76: 931-950.

Birklund, J. - 1977. Biomass, growth and production of the amphipod Corophium insidiosum Crawford, and preliminary notes on Corophium volutator (Pallas). Ophelia, 16: 187-203.

Brian, A. - 1939. Gli Anfipodi della laguna di Venezia (nota preliminare). Boll. Ist. Zool. Anat. Comp., Univ. Genova, 19 (110): $8 \mathrm{pp}$.

Bousfield, E.L. and P.M. Hoover. - 1997. The amphipod superfamily Corophioidea on the Pacific Coast of North America. Part V. Family Corophiidae. Corophiinae new subfamily. Sistematics and distributional ecology. Amphipacifica 2(3): 67-139.

Casabianca, (de M.L.). - 1967. Sur la biologie de Corophium insidiosum Crawford dans l'étang de Biguglia (Corse). Bull. Soc. Zool. France, 91 : 401-405.

Casabianca, (de M.L.). - 1968. Sur le cycle annuel des populations de Corophium insidium [i.e. insidiosum] Crawford dans l'étang de Biguglia (Corse), et ses variations dans des conditions exceptionnelles. Vie Milieu, 19: 159-164.

Casabianca, (de M.L.). - 1972/73. Influence des apports d'eau douce sur la dynamique des populations de Crustacés constructeurs de l'étang de Buguglia, Corse (Corophium insidiosum C., Tanais cavolinii M.E., Ericthonius brasiliensis D.). Vie Milieu, 23C: 46-63.

Casabianca, (de M.L.). - 1975. Méthode de calcul de la production par estimation de la mortalité. Application à une population à structure complexe du crustacé Corophium insidiosum Crawford (lagune de Biguglia, Corse). Comptes Rendues des Séances, Acad. Sci. Paris, 280:1139-1142.

Casabianca, (de M.L.). - 1979. Influence de la mise en valeur agricole sur l'évolution biocénotique des bords d'étangs corses. Rev. Biol. Ecol. Médit., 5: 211-226.

Costa, F.O. and M.H. Costa. - 1999. Life history of the amphipod Gammarus locusta in the Sado estuary. Acta Oecol., 20(4): 305-314.

Crawford, G.I. - 1937. A review of the amphipod genus Corophium with notes on the British species. J. Mar. Biol. Ass. U. K., 21: 589- 630.

Cunha, M.R., J.C. Sorbe. and M.H. Moreira. - 2000. The amphipod Corophium multisetosum (Corophiidae) in Ria de Aveiro (NW
Portugal). I. Life history and aspects of reproductive biology. Mar. Biol., 137: 637-650.

Dahl, E. - 1973. Ecological range of Baltic and North Sea species. Oikos, 15, 85-90.

Fischetti, E. - 1937. Cenobiosi della scogliera di S. GiulianoBoccadasse, con speciale riguardo agli Anfipodi. Boll. Mus. Lab. Zool. Anat. Comp. Univ. Genova, 17(96): 17pp.

Harding, J.P. - 1949. The use of probability paper for the graphical analysis of polymodal frequency distributions. J. Mar. Biol. Ass. U.K., 28:141-153

Janssen, H., M. Scheepmaker, M. Van Couwelaar and S. Pinkster. - 1979. Biology and distribution of Gammarus aequicauda and G. insensibilis (Crustacea: Amphipoda) in the lagoon system of Bages- Sigean (France). Bijdragen tot de Dierkunde, 49: 42-70.

Jensen, K.T. and L.D. Kristensen. - 1990. A field experiment on competition between Corophium volutator (Pallas) and Corophium arenarium Crawford (Crustacea :Amphipoda) effects on survival, reproduction and recruitment. J. exp. mar. Biol. Ecol., 137: 1-24.

Kevrekidis, T. - 2004. Population dynamics, growth and reproduction of Corophium insidiosum (Crustacea: Amphipoda) at low salinities in Monolimni lagoon (Evros Delta, North Aegean Sea). Hydrobiologia, 522: 117-132.

Köhn, J. - 1996. Amphipods of the Baltic Sea. Pols. Archiw. Hydrobiol., 42: 385-394.

Krapp-Schickel, G. - 1971. Meereresamphipoden aus Taranto. Mem. Mus. Civ. St. Nat. Verona, 18: 343- 367.

Labourg, P.J. - 1968. Cycle reproducteur annuel à Archachon de Corophium insidiosum Crawford, amphipode Corophiidae. Actes Soc. Linn. Bordeaux, 105: 1-16.

Moore, P.G. - 1981. The life histories of the amphipods Lembos websteri Bate and Corophium bonnellii Milne Edwards in kelp holdfasts. J. Exp. Mar. Biol. Ecol., 49: 1-50.

Muskó, I.B. - 1992. Life history of Corophium curvispinum G.O. Sars (Crustacea, Amphipoda) living on macrophytes in Lake Balaton. Hydrobiologia, 243/244: 197-202.

Muus, B.J. - 1967. The fauna of Danish estuaries and lagoons. Meddr. Danm. Fisk. Havundres, 5: 1-316.

Myers, A.A. - 1982. Corophiidae. In: S. Ruffo (ed.), The Amphipoda of the Mediterranean. Mem. Inst. Oceanogr. Monaco,. 13: 185-209.

Nair, K.K.C. and K. Anger. - 1979. Life cycle of Corophium insidiosum (Crustacea, Amphipoda) in laboratory culture. Helgoländer wiss. Meeresunters., 32: 279-294.

Persson, L.E. - 1999. Growth and reproduction in two brackish water populations of Orchestia gammarellus (Amphipoda: Talitridae) in the Baltic Sea. J. Crust. Biol., 19(1): 53-59.

Prato E. and F. Biandolino. - 2003. Seasonal changes in population of the Amphipod Gammarus aequicauda. Medit. Ma. Sci., 4/1: 49-56.

Procaccini, G. and M.B. Scipione. - 1992. Observation on the spatio-temporal distribution of Crustacean Amphipods in the Fusaro coastal lagoon (central Tyrrhnian sea, Italy) and some notes on their presence in the Mediterranean lagoons. Mar. Ecol.: Pubbl. Staz. Zool. Napoli, 13: 203-224.

Rajagopal, S., G. van der Velde, B.G.P. Paffen, F.W.B. van de Brink and A. Bij de Vaate. - 1999. Life history and reproductive biology of the invasive Corophium curvispinosum (Crustacea: Amphipoda) in the Lower Rhine. Archiv. Fur Hydrobiologie, 144: 305-325.

Sheader, M. - 1978. Distribution and reproductive biology of Corophium insidiosum (Amphipoda) on the north-east of England. J. Mar. Biol. Ass. U. K., 58: 585-596.

Wenner, A.M. - 1972. Sex ratio as a function of size in marine Crustacea. Am. Nat., 106:321-350.

Scient. ed.: J.E. Cartes

Received February 10, 2005. Accepted March 16, 2006.

Published online June 30, 2006 